\title{
Elohopeaa kynnyksen alla, kolikoita seinän sisässä
}

\author{
Hukantaival, Sonja 2016: "For a Witch Cannot Cross Such a Threshold!" \\ Building Concealment Traditions in Finland c. 1200-1950.
}

Turku: Suomen keskiajan arkeologian seura. 396 sivua.

\section{Pasi Enges}

\footnotetext{
Kansanusko mielletään helposti ennen kaikkea uskontotieteen ja folkloristiikan tutkimuskohteeksi. Monen tieteenalan panos on kuitenkin tarpeen, kun muodostetaan kokonaiskuvaa suomalaisen kansanuskon eri ilmenemismuodoista, ja sanansa on sanottavana niin perinne-, kieli- kuin historiatieteilläkin. Toinen asia on, miten eri tieteenalat ja niiden tyypillisesti hyödyntämät aineistot kohtaavat käytännössä. Nyt arvioitavana oleva väitöskirja on esimerkki hyvin onnistuneesta tieteenalojen rajat ylittävästä tutkimusasetelmasta.
}

Sonja Hukantaival on arkeologian alaan kuuluvassa, rakennusten suojelutaikuutta koskevassa väitöskirjassaan hyödyntänyt kahta aineistoa: tutkimuksen synteesi rakentuu historiallisen ajan esinelöytöjen ja niitä pääosin ajallisesti myöhäisempien folkloreaineistojen rinnakkain- ja ristiintulkinnalle. Näiden pääaineistojen ohella aiheeseen tuo lisävalaistusta suppean oikeudenkäyntipöytäkirja-aineiston analyysi. Lähtöoletuksena on, että moniaineistoisuus takaa pelkkään esineaineiston analyysiin perustuvaa tulkintaa monipuolisemman ja siten todenmukaisemman kuvan tutkimuksen kohteena olevasta ilmiöstä.

\section{Folkloristista arkeologiaa}

Hukantaival on asettanut väitöskirjalleen kolme tavoitetta: 1) suomalaisen rakennuskätköperinteen yleiskartoitus, 2) kätköjen merkitysten selvittäminen niitä tehneiden ihmisten maailmankuvassa ja 3) arkeologisen kansanuskontutkimuksen teorian ja moniaineistoisen metodin kehittäminen. Ensin mainittujen kohdalla huomio kohdistuu, paitsi yleiskuvan rakentamiseen, myös ilmiön alueelliseen ja ajalliseen variaatioon. Alueellisesti tutkimus kattaa koko Suomen ja sen aikajänne on pitkä. Kätkölöydöt on analyysia varten jaettu kolmeen periodiin: keskiaikaan (noin 1200-1500), uuteen aikaan (1500-1700) ja uusimpaan aikaan (1700-1950).

Folkloristin näkökulmasta kiinnostavaa on, että pääosin Suomalaisen Kirjallisuuden Seuran kokoelmiin kertyneet taikamuistiinpanot eivät tässä tutkimuksessa ole pelkästään 
arkeologisten löytöjen tulkintaa tukevaa taustatietoa, vaan ne nostettu tasavertaiseksi tutkimusaineistoksi esineaineistojen rinnalle. Keruu- ja tutkimushistoriallisista syistä sekä esineettä folkloredokumentteja on määrällisesti eniten uusimmalta ajalta, taikamuistiinpanoja varsinaisesti vasta 1800-luvun lopulta lähtien. Hukantaival soveltaa tutkimuksensa metodologiana historiallisen jatkuvuuden lähestymistapaa, jossa liikkeelle lähdetään parhaiten dokumentoidusta ajanjaksosta ja seurataan tutkittavaa ilmiötä ajassa taaksepäin. Analyysin metodologinen kehys täydentyy yhdistämällä historiallisen jatkuvuuden lähestymistapaan kontekstuaalinen metodi, joka tähtää aineistossa toistuvien kaavojen (yhtäläisyyksien ja erojen) havaitsemiseen. Kysymyksessä on nimenomaan tämän tutkimuksen tarpeisiin kehitetty menetelmällinen sovellus, sillä käytettävissä oleva tutkimusmateriaali ei taivu kontekstuaaliselle metodille luonteenomaiseen tilastolliseen käsittelyyn ja tilastollisten merkittävyyksien laskemiseen.

Rakenteeltaan väitöskirja on mallikelpoinen. Se koostuu kolmesta osasta, joista ensimmäinen ("Foundation") pitää sisällään lyhyen johdannon, tutkimuksen teoreettisen viitekehyksen, metodien ja tutkimusaineistojen muodostamisen kuvauksen, tutkimushistoriallisen katsauksen ja ilmiötä ympäröivän maantieteellisen, historiallisen ja yhteiskunnallisen kontekstin esittelyn. Toinen osa ("Material") alkaa tutkimusaineistojen tarkemmalla erittelyllä, jonka tulokset on tiivistetty lukuisiin kaavioihin ja karttoihin. Näiden avulla lukijan on helppo muodostaa kokonaiskuva aineistojen maantieteellisestä, ajallisesta ja määrällisestä jakautumisesta. Analyysin ja sen tulosten julkituonnissa erilaiset kuviot ja taulukot ovat itse asiassa koko työn läpäisevä ja tekijän runsaasti käyttämä esityskeino.

Aineiston kuvauksesta edetään ensin kätkettyjen esineiden ja niiden erilaisten kätköpaikkojen yksityiskohtaisempaan analyysiin sekä folkloreaineiston että esinelöytöjen osalta. Erityisen kiinnostava on tämän osan viimeinen luku, jossa vedetään yhteen tutkimusaineistoista löytyvät merkitykset ja kaavat; siinä koetellaan moniaineistoisen tutkimuksen metodologinen perusta. Käykin ilmi, että kumpikaan pääaineistoista ei yksin riittäisi kattavan kuvan luomiseen kätköperinteistä. Analyysin paljastamat yhtäläisyydet ja erot aineistoryhmien välillä osoittautuvat merkityksellisiksi ja kumpikin aineisto tuo ilmi sellaista, mikä toisesta puuttuu kokonaan. Taikamuistiinpanoissa tulee esiin sellaisia substansseja kuten elohopea ja maatuvat eloperäiset ainekset, joita harvoin on mahdollista tavoittaa arkeologian keinoin. Esinelöydöissä taas painottuvat kivikautiset kiviesineet ja muut esineet, joista on laajassa folkloreaineistossa vain yksittäisiä mainintoja. Substanssin tai esineen tarkastelu suhteessa sen sijoituspaikkaan rakennuksessa paljastaa niin ikään merkitseviä säännönmukaisuuksia ja painotuksia.

Tutkimuksen kolmannessa osassa ("Construction") siirrytään analyysin tulosten tulkintaan. Osan luvut osoittavat arkeologisen näkökulman hedelmällisyyden ja tärkeyden kansanuskon ja laajemminkin henkisen perinteen tutkimuksessa. Kätkölöytöjen ja arkistomuistiinpanojen peilaamasta materiaalisesta todellisuudesta siirrytään kätköjä tehneiden ihmisten maailmankuvaan ja merkityksiin, joita kätköillä todennäköisesti on eri aikoina ja eri alueilla ollut. Tekijä osoittaa myös tervettä kriittisyyttä saavuttamiaan tuloksia kohtaan ja pidättäytyy tekemästä liian suoraviivaisia johtopäätöksiä; aineiston myöhäisintä kerrostumaa edustavat taikamuistiinpanot antavat osviittaa vanhempien esinelöytöjen tulkinnalle, mutta eivät sellaisinaan selitä niitä. Tärkeäksi eroksi folklore- ja esineaineistojen välillä niiden merkitysten tulkinnassa osoittautuu kätkön tekijän aie, joka valtaosassa taikamuistiinpanoja on ilmaistu eksplisiittisesti, mutta jää esinelöydöissä tulkinnanvaraiseksi. Kansanomaisen 
maailmankuvan ja väki-ajattelun tuntemus antavat tutkijalle välineitä tehdä perusteltuja tulkintoja sinänsä usein arkisten aineiden ja esineiden rituaalisesta käytöstä.

\section{Abstraktit käsitteet ja esineiden konkretia}

Tutkimuksen avaintermeiksi Sonja Hukantaival listaa maailmankuvan, kansanuskon, rituaalin, uhrin ja taikuuden. Nämä kaikki ovat kansanuskon tutkimuksen keskeisterminologiaa ja käsitteinä abstrakteja, monitulkintaisia ja kiistanalaisiakin. Lähinnä tekijän oppineisuuden osoittamiseksi lienee tulkittava laajahkon niitä koskevan teoreettisen keskustelun ottaminen mukaan teokseen; työssä sovelletut, tämän kertaista tutkimusta palvelevat työmääritelmät tuntuvat täysin riittäviltä asian ymmärtämiseksi. Kieltämättä käsiteanalyysi on ajatuksia herättävää, ja on mielenkiintoista pohtia esimerkiksi sitä, tulisiko rakennuskätköjä tarkastella osana erityistä magian kategoriaa vai olisiko kyseessä proosallisemmin omana aikanaan tyypillinen ja arkinen osa rakennustekniikkaa. Hieman erikoinen ratkaisu on tämän keskustelun sijoittaminen leipätekstin sijasta erilliseen, suhteellisen laajaan liitteeseen.

Lähdeluettelo ja liitteet kattavat lähes puolet kirjan kokonaissivumäärästä, eikä epäilyille tekijän perusteellisuudesta ja asiantuntemuksesta jää sijaa. Lähdeluettelo on pitkä ja osoittaa, että Hukantaival on perehtynyt laajasti ja perusteellisesti aiheeseensa liittyvään tutkimukseen. Kiitoksen ansaitsee myös koko tutkimusaineiston ja sen analyysin perusteellinen esillepano. Folkloreaineisto on esitetty omana liitteenään tietoyksikön tarkkuudella ja tavanomaisten lähdetietojen lisäksi jokaisen kohdalla on ilmoitettu myös taiassa käytetty objekti ja sen kätköpaikka. Esinelöydöt listaavasta liitteestä puolestaan lukija saa hyvin yksityiskohtaisen kuvauksen jokaisesta löydöstä ja sen kätköpaikasta sekä runsaasti taustatietoa esineen löytö- ja tulkintahistoriasta. Lisäksi jokaisen esineen lähdearvosta on esitetty kriittinen arvio perusteluineen. Yhteen liitteeseen on vielä ristiintaulukoitu folkloreaineiston tiedot kätkettyjen esineiden suhteesta erilaisiin rakennuksiin, eri paikkoihin rakennuksessa ja eri käyttötarkoituksiin sekä yleisimpien esineiden maantieteellinen ja määrällinen jakautuminen. Harvoin tutkimuksissa tuodaan näin yksityiskohtaisesti aineisto ja sen analyysi lukijan ulottuville.

\section{Tärkeä metodologinen avaus}

Väitöskirjan ansiot tutkimuksen kohteena olevan ilmiön selvittämisessä ovat ilmeiset, ja tutkimus toimii erinomaisesti suomalaisen rakennuskätköperinteen yleiskartoituksena. Myös esinekätköjen tulkinta oman aikansa kontekstissa ja havainnot niiden ajallisista ja alueellisista muutoksista ovat varsin syvälle meneviä ja hyvin perusteltuja, unohtamatta kuitenkaan aineistojen luonteesta seuraavia vinoutumia ja niiden asettamia tulkinnallisia rajoja. Kolmesta tutkimukselle asetetusta tavoitteesta kaksi ensimmäistä on siis täyttynyt onnistuneesti. Entä kolmas tavoite, arkeologisen kansanuskontutkimuksen teorian ja moniaineistoisen metodin kehittäminen?

Arkeologinen lähestymistapa kansanuskoon ei ole uusi ilmiö ja se on tuottanut merkittäviä tuloksia - ajateltakoon vaikkapa Unto Salon massiivista arkeologian, kielihistorian ja kulttuurihistorian näkökulmiin perustuvaa synteesiä kalevalamittaisessa runoudessa välittyneistä myyteistä ja uskomuksista (Salo 2012). Suomalaisen kansanuskon tutkimustraditioissa ovat kuitenkin viime vuosiin saakka painottuneet sen aineettomat ja sanalliset ilmenemismuodot; kansanuskon materiaalinen puoli (myös arkeologinen esineistö) on ollut sivuosassa, ja sitä 
on usein tarkasteltu vain henkisen kontekstina, kuvituksena tai symbolina. Hukantaipaleen sivumennen käyttämä termi kansanuskon arkeologia on itse asiassa tärkeä askel kansanuskon aineellisuuden suuntaan. Kuten tekijä itse toteaa, on tässä tutkimuksessa keskitytty kansanuskon yhteen pieneen osa-alueeseen, ja on selvää, että arkeologian näkökulmien ja arkeologisten löytöjen hyödyntämismahdollisuuksilla aihepiirin koko tutkimuskentässä on rajansa. Moniaineistoinen ja kontekstuaalinen menetelmä näyttäisi kuitenkin sopivan myös muiden osa-alueiden tutkimukseen. Tulevaisuus näyttää, mitä nämä osa-alueet ovat ja miten menetelmä niiden kohdalla mahdollisesti toimii ja kehittyy. Nyt käsillä oleva tutkimus on lähtökohdiltaan selkeästi arkeologinen, mutta samalla se osoittaa tieteenalojen rajoja ylittävän lähestymistavan vahvuudet. Hukantaipaleen väitöskirjaan tutustumista voi suositella kaikille suomalaisesta kansanuskosta ja sen erilaisista tutkimusmahdollisuuksista kiinnostuneille.

\section{Kirjallisuus}

Salo, Unto 2012: Kalevalaiset myytit ja uskomukset I-III. Somero: Amanita.

Filosofian tohtori Pasi Enges toimii folkloristiikan yliopistonlehtorina Turun yliopistossa. 
(19) 